\title{
A STUDY ON JOB STRESS AND WORK-FAMILY CONFLICT
}

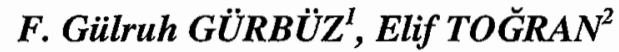 \\ ${ }^{\prime}$ Marmara Üniversitesi, İ.İ.B.F., Ingilizce İsletme Bölümü, Yardımcı Doçent Dr. \\ ${ }^{2}$ Marmara Üniversitesi, Sosyal Bilimler Enstitüsü, Yüksek Lisans. Öğrencisi
}

\section{A STUDY ON JOB STRESS AND WORK-FAMILY CONFLICT}

\begin{abstract}
Today women an important part of the total workforce are women. The ones who are able to balance their work life and their family life can be very successful in their businesses. The aim of this study is to analyze the relationship between job satisfaction and job stress of female employees and to investigate the effects of marital status, presence, age and number of children on their job stress levels. In addition, the relationship between the demographic variables, age and educational levels of female employees and job stress is also examined in order to determine whether these variables have any influence on job stress levels.
\end{abstract}

The data to be in this study were obtained from female employees working in two different audit companies in Istanbul. A questionnaire consisting of 41 items was administered to female employees. Results were tested through statistical analysis depending on the types of the variables. According to research results four of five hypotheses were accepted.

Keywords: Job Stress, Job Satisfaction, Work- Family Conflict

\section{INTRODUCTION}

Nowadays, we as human beings cannot escape from stress because stress and stress creating conditions are everywhere both in our private and professional life. For that reason, many research studies have been done on stress. In a recent nation-wide study of occupational stress in the U.S., the proportion of workers who reported, "feeling highly stressed" had more than doubled from 1985 to 1990. Those reporting, "having multiple stressrelated illnesses" increased from $13 \%$ to $25 \%$. Moreover, $69 \%$ of the 600 workers surveyed in the Northwestern National Life study reported that their productivity was reduced because of high stress levels, and "one of in three say job stress is the single greatest stress in their lives" [1].

Job stress can be viewed as an individual's reaction to work environment characteristics that appear

\section{A STUDY ON JOB STRESS AND WORK-FAMILY CONFLICT}

Özet: Günümüzde, çalışan bayanların işgücünün önemli bir parçasını oluşturduklart düşünüliürse, sirketlerin calışanlarının başarlarının ve buna bağlı olarak da kendi başarılarının temelinin, sağllklı bir iş-aile hayatı dengesi kurmakla sağlanacağını anlamaları gerekmektedir.Bu doğrultuda çalışmamizın amacı, çalışan bayanların iş stresi ve is tatmini arastndaki ilişkiyi incelemek ve medeni durum, cocuk sahibi olmak, cocuklartn yaşl ve saytsintn is stresi seviyesi üzerindeki etkisini araștırmakttr. Ayrica, yaş ve eğitim dïzeyi gibi demografik karakterli değişkenlerin, çalışan bayanlarn is stresi seviyelerinde herhangi bir etkileri olup olmadığın saptayabilmek için, bu değişkenler de analize dahil edilmiştir.

Bu çalışma için kullanılacak veriler, İstanbul'daki iki denetim şirketinde çalışan bayanlara, 41 sorudan oluşan bir anket uygulanmak suretiyle elde edilmiştir. Araşturma sonuçlar değişkenlerin tipine göre, çeșitli istatistiksel analizler kullanilmak suretiyle test edilmiştir. Araştırma sonuçlarına göre, beş hipotezden dördü doğrulanmıs, bir tanesi ise doğrulanamamıştır.

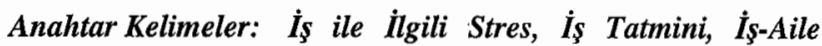
Çatı̧̧mast

threatening to the individual. It indicates a poor fit between the individual abilities and the work environment in which either excessive demand is made from the individual, or the individual is not fully equipped to handle a particular situation. More recently, job stress is defined as a discrepancy between an employee's perceived state and desired state, provided that the presence of this discrepancy is considered important by the employee [2]. Organizational stress is defined as a problematic level of environmental demand that interacts with the individual to change his/her psychological or physiological condition such that the person is forced to deviate from normal functioning and personal life [3]. When the relationship between an individual actor and the work environment comes to be marked with excessive stress, there are adverse consequences for both the organization's effectiveness and the individual's well being [4]. 
Stress in the workplace is a major problem, with extensive costs to individuals, organizations and society. It is now well established from the perspective of the organization that, high levels of stress within the work force can result in poor productivity, absenteeism, high turnover and worker grievances. Growing concerns over the consequences of job stress for both employees and organizations have stimulated efforts to understand the sources and consequences of stressors -physical or psychological demands from the environment that cause stress- in the workplace. Stressors can take a variety of forms caused by family, friends or the organization. Organizational stressors are characterized by factors that reflect the organization itself (size, number of levels, rules) as well as factors that relate to position and interaction of people (role conflict and role ambiguity). Specifically what makes an organization more stress creating than another depends on the predominance of certain properties: Work overload, underwork, role ambiguity, organizational structure, role conflict, being responsible of managing people and traveling a lot. Among the organizational stressors cited above, role ambiguity, role conflict and role overload are the ones, which attracted the attention of and were studied by most of the organizational stress researchers. It has been argued that that role ambiguity, role conflict and role overload are the stressors most frequently cited in literature that are shown to be among the antecedents of work stress [5].

Job satisfaction is an indication of how individuals feel about their job when their expectations are compared to what is actually received from different facets of the work situation [6]. Job satisfaction, being one of the most frequently studied topics in research, has been well established as an outcome of job stress. When employees are satisfied with various dimensions of their jobs, their levels of job satisfaction are expected to be high. In the same token employees who are dissatisfied with their jobs are significantly more likely to report that their jobs are stressful [7].

Work-family conflict is another arena exacerbating the effects of job stress. Work conflict is defined as the extent to which a person experiences incompatible pressures within the work domain and family conflict is defined as the extent to which a person experiences incompatible pressures within the family domain [8]. Work-family conflict is defined as a form of interrole conflict in which the role pressures from the work and family domains are mutually incompatible in some respect. This is, participation in the work (family) role is made more difficult by virtue of participation in the family (work) role. Work-family conflict occurs when an individual has to perform multiple roles; worker, spouse, and, in many cases, parent. Each of these roles imposes demands requiring time, energy and commitment [9]. Since when work interferes with family life, pressure is often placed on individuals to spend less time at work and more time with their families. The family demands lead to physical unavailability for work due to family responsibilities; preoccupation with family activities and energy depletion will be positively related to work-family conflict [10].

The economic pressures of inflation and the social and psychological need to develop one's self-identity are encouraging women to take a more active role outside home to pursue full time careers, and to participate more widely in society in general. Women are increasingly being forced to deal with job-related demands that limit their performance of family roles. These trends are resulting in increased levels of work-family conflict as men and women try to balance the conflicting demands of work and family [11]. Literature indicates that the interaction of work and family is an area of stress particularly for women in management and professional areas. Workingwomen often feel conflict about the combination of these roles. Since women have stronger personal, social and society pressure to adhere to the roles focusing on family and household tasks, working women experience the strains of competing work and family demands [12].

\section{OBJECTIVES OF THE STUDY}

The aim of this research is to analyze the relationship between job satisfaction and job stress of female employees and to investigate the effects of marital status, presence, age and number of children on job stress levels. Through an extensive literature review, it was observed that it would be more sound and logical to analyze only the females. There are various reasons for this approach:

- In our literature survey we have seen that studies on job stress of women have been neglected and additional research was needed to increase the depth of knowledge concerning the special needs of women $[13,14]$. Also, until recently, theories and research about job stress have been directed primarily at men's experiences and as a result, women's experiences of stress have remained relatively unexplored [15].

- Men's believes and attitudes about the different aspects of their work and family are very different from women's. Some of these are as follows:

a) When family responsibilities interfere with their jobs, male employees do not deem this as a negative aspect of their jobs since they have more freedom than most female employees to adjust their schedules to accommodate family issues before they create an aggravating situation [7]. 
b) Work and family roles have different meanings for men and women. Women see work as prevention from taking care of their family properly and fulfilling their primary role as spouse and caregiver, whereas men see work as the key importance and as the foundation of their family roles, which will lead them to take care of their families. This difference in meaning and the acquisition of multiple roles is then interpreted as the cause for women's higher levels of distress [16].

c) Women regard marriage as a more important event in their lives than do men and, as they must make the greater adjustments; one would expect to find greater emotional problems in married women than unmarried [17]. It is widely recognized that working women typically maintain major responsibility for their home and family and thus more often bear the burdens of role overload and role conflict than men. Thus the stress of being both a homemaker and career woman would lead to proportionately more severe strains [18].

d) Childcare is also another unique stressor for women. Although fathers may be cooperative, childcare usually remains the mother's responsibility. The working mother feels guilty about not spending more time with her children [13].

On the other hand, women also indicated that work would play an important and negative role in their decisions about childbearing, while men reported more often than women that being a parent had a very positive effect on their work. Women appear to assume primary responsibility in household and childcare tasks beside their paid worker role. Even for women without children, work is seen as having negative impact on decisions about childbearing, whereas for men, being a parent is reported to have a positive effect on work [19].

e) Women also reported more often than men that they worried about household responsibilities while at work. In addition, women that were studied on reported far more frequently than men did that they worried about home responsibilities at work and work responsibilities at home. This suggests that clear role boundaries may be more difficult for women to maintain [19].

The nature of work performed at audit firms was the major criteria for selection. Audit work requires a high overload of work that has to be done in a limited amount of time, within predetermined deadlines by the audit client and the job manager, leading to a considerable amount of stress.

For an in-depth understanding of the various factors affecting the job stress of female employees, some other variables were identified for further analysis. Married working women typically maintain major responsibility for home and family. Thus trying to fulfill the roles of both a homemaker and career woman creates a considerable amount of stress on women. When the issue of having children comes into the arena, women's roles become heavier with the addition of the mother role, the amount of stress experienced by them increase, since women assume childcare as their primary responsibility. Based on these factors, the research aims to investigate the effect of marital status and the presence of children on the job stress levels of female employees.

It has been argued that that both numbers of children and their ages may be associated with physical unavailability for work, preoccupation with childrearing activities and overload [10,20]. Past research findings also assert the view that working mothers with pre-school or school-age children are more vulnerable to stress than mothers with older children. Since when the children are young and dependent, the family responsibilities are more demanding and the mothers feel more negative spillover from family to work in the form of energy deficit and preoccupation with family matters. Thus, the research aims to analyze the effect of the number and age of children on job stress levels of female employees. Taking all these findings into consideration, it was found out that including male employees in the sample would only distort the results and would not help for a logical comparison of the findings. Thus, to be able to obtain healthy research results, female employees were selected as sample.

\section{HYPOTHESES}

From the theoretical framework discussed above, five hypotheses were developed for this research. They are as follows:

Ha 1. The higher the job satisfaction levels of female employees, the lower their job stress levels will be.

Ha 2. There will be difference in job stress levels between married and single female employees.

Ha 3. There will be difference in job stress levels among female employees having children and female employees having no children.

Ha 4. There will be difference in job stress levels among female employees having preschool and primary school age children and female employees having older children.

Ha 5. The job stress levels of female employees will increase as the number of children they have increased. 


\section{RESEARCH DESIGN}

The purpose of this study is to find out the relationship between the dependent variable job stress and the independent variable job satisfaction and to investigate the effects of the independent variables of marital status, presence, age and number of children on the job stress levels of female employees. In addition, the relationship between the demographic variables, age and educational levels of female employees and job stress will also examined in order to determine whether these variables have any influence on job stress levels. Thus, this study is a correlation study rather than a causal study; it is analytical in nature rather than a predictive one.

As being the unit of analysis, the data for the study were collected from each individual employee via questionnaire technique in their natural work environment in a one-month period. Variables are neither controlled nor manipulated and also no artificial setting is created for the study. Because neither previous research had been done by the researchers on the sample, nor was any subsequent extension of the research contemplated, the study was cross-sectional in nature.

\section{IV.1. Population And Sample}

The population for this study comprised of all female employees in the audit departments of two different audit companies in İstanbul. A questionnaire consisting of 41 items was administered to a sample of 141 employees from different occupational levels, selected through a convenience sampling method. The sample could not be chosen at random due to the administrative difficulties that would occur in the companies and most importantly due to the nature of audit firms of full-time unavailability of all the company personnel. Instead, most readily available female employees from different occupational levels were asked to voluntarily participate in the study. 123 questionnaires were filled out by the employees and returned to the researcher implying $87 \%$ response rate.

\section{IV.2. Data-Collection Methods}

The questionnaire was distributed to the employees during office hours and the ones that were not busy at that time filled out the questionnaire in 5-10 minutes and handed them back immediately, whereas the busy employees filled out and returned the questionnaires in 10 days time. The subjects of the sample consisted of partners, managers (experienced and associate), seniors (experienced and first year), assistants (experienced and first year), secretaries and office clerks. The subjects were only females. These female employees differed on the basis of age, $46.3 \%$ were between $25-35,37.4 \%$ were below $25,11.4 \%$ were between $36-45,4.1 \%$ were between $46-55$ and $0.8 \%$ were over 55 years of age.
$50.4 \%$ of the female employees were married and $49.6 \%$ were single. $69.9 \%$ had university education, $17.9 \%$ had high school education and $12.2 \%$ had master's degree. $78 \%$ of the female employees did not have any children and $22 \%$ had children. Of this $22 \%$ of female employees having children, $17.1 \%$ had children of preschool and primary school age and $4.9 \%$ had older children. $17.1 \%$ of female employees had only one child, $4.1 \%$ had two children and $0.8 \%$ had three children.

\section{IV.3. Questionnaire Design, Variables, and Measures}

In this study the questionnaire was composed of three different parts. In the first part, there were questions developed by the researchers measuring the demographic variables: Age, marital status, education level, having children or not, number of children and age of the children.

In the second part, the dependent variable of job stress of female workers was measured by the Job-Related Tension Index [8]. The respondents were expected to answer 15 questions about how frequently they felt bothered about the named features of their work on a five point Likert scale. In an attempt to define job stress operationally and in order to find out the level of job stress of female employees, different dimensions that were concerned with the nature of work and the work environment were analyzed.

In the third part, the independent variable of job satisfaction was measured by the short form of Minnesota Satisfaction Questionnaire (MSQ) [21]. The questionnaire consisted of 20 questions. In an attempt to define job satisfaction operationally and in order to find out the job satisfaction levels of female employees, different dimensions that were concerned with the nature of work and the work environment were analyzed. The questionnaire required respondents to answer how much they were satisfied with the different features of their jobs such as pay, promotion, supervision, co-workers, the working conditions etc. on a five point Likert Scale.

\section{IV.4. Data-Analysis Methods}

First of all, frequency distributions were used to describe the sample. Then Cronbach's alpha was established for the dependent and the independent variables. Later on, the means, the standard deviations and the variances for the dependent and the independent variables were calculated. After these steps, various statistical analyses were used to test the hypotheses. The relationship between the dependent variable, job stress and the independent variable, job satisfaction has been analyzed by using the Pearson Correlation Analysis. For the relationship between the independent variable of number of children and job stress, again Pearson Correlation Analysis was utilized. In order to investigate 
the effects of the independent variables, marital status and presence of children on the dependent variable job stress, independent samples t-tests were used. In order to assess the impact of the independent variable, age of children on the dependent variable job stress, again an independent samples t-Test was performed. In addition, One-way Analysis of Variance (ANOVA) tests were utilized to determine whether there would be differences in the job stress levels of female employees according to different age groups and educational levels.

\section{RESULTS}

Research statistical evaluation was performed by an SPSS Program version 6.0. A significance level of .05 was determined for the evaluation of the statistical analyses. The mean, standard deviation and the variance of the dependent variable, job stress (total job stress score) and the independent variable, job satisfaction (total job satisfaction score) are summarized in the Table.1 below:

Table.1: Statistical Information for Job Stress and Job Satisfaction

\begin{tabular}{|l|l|l|l|}
\hline Variables & Mean & $\begin{array}{l}\text { Standard } \\
\text { Deviation }\end{array}$ & Variance \\
\hline Job Stress & 37.30 & 8.17 & 66.72 \\
\hline $\begin{array}{l}\text { Job } \\
\text { Satisfaction }\end{array}$ & 65.96 & 13.64 & 186.04 \\
\hline
\end{tabular}

In addition the minimum and the maximum figures for total job stress score were 17 and 59, while for total job satisfaction score were 33 and 99.

In this study, the reliability analysis was performed for the dependent variable of job stress and the independent variable of job satisfaction. However, for the independent variables of marital status, presence, age and number of children, a reliability analysis could not be performed. Since they were all single item measures. When performing the reliability analysis, these criteria were used; recomputation of the Cronbach's alpha after the extraction of the items, the corrected item-total correlation, and squared multiple correlation.

An item analysis was conducted to understand whether or not all the 15 items measuring job stress should be retained in further analysis. All respondents $(\mathrm{N}=123)$ were included in this analysis. In addition, a reliability analysis was carried out by correlating each relevant item with the respective total scale (excluding the item itself). The results indicated that no item in the full scale had an alpha lower than .82 and the Cronbach's alpha for the full scale was .83 . The same analysis was conducted for the 20 items measuring job satisfaction and it showed that no item in the full scale had an alpha lower than .89 and Cronbach's alpha for full scale was .90 . When the results of the corrected item-total correlation are observed, it can be noticed that there are no items with negative values or approaching to zero. In addition, the results of the squared multiple correlations indicate that the extent to which given answers of one item can express total answers of all other items is quite high. All these results show that there are no items that should be excluded in further analysis and the high Cronbach's alpha for both of the variables indicate that the internal consistency of measures used in the study can be considered good.

\section{Hypothesis 1:}

Ho: There will be no relationship between the job stress levels and job satisfaction levels of female employees.

Ha: The higher the job satisfaction levels of female employees, the lower their job stress levels will be.

In order to analyze the relationship between the dependent variable of job stress and the independent variable of job satisfaction, Pearson Correlation Analysis has been utilized. Since both variables are measured on an interval scale, it would be more meaningful to investigate the relationship by conducting a correlation test. The test results showed a significant negative correlation $(r=-.47$; $\mathrm{p}=.000$ ) between job stress and job satisfaction. Since $\mathrm{p}=.000 \leq .05$, the null hypothesis was rejected at .05 significance level $(\alpha)$ and the alternate hypothesis was accepted. This showed that as the job satisfaction levels of female employees increased, their job stress levels decreased. Table. 2 below indicates the test results:

Table.2: Pearson Correlation Results between Job Stress and Job Satisfaction

\begin{tabular}{|l|l|l|l|}
\hline Variables & $\begin{array}{l}\text { No. of } \\
\text { Cases }\end{array}$ & $\begin{array}{l}\text { Corr. Coeff. } \\
(\mathrm{r})\end{array}$ & P-value \\
\hline $\begin{array}{c}\text { Job Stress vs. } \\
\text { Job Satisfactio }\end{array}$ & 123 & -.4681 & .000 \\
\hline
\end{tabular}

\section{Hypothesis 2:}

Ho: There will be no difference in job stress levels between married and single female employees.

Ha: There will be difference in job stress levels between married and single female employees. 
To test for statistical significance, an Independent Samples t-Test was established. A t-Test is used to see if there are any significant differences in the means for two groups. An Independent Samples T-Test is used with groups that do not share pairs of scores. In order to obtain the most healthy and logical results, the grouping variable should be measured on a nominal scale and the dependent variable should be measured either on an interval or a ratio scale. In this hypothesis, the grouping variable that is the independent variable of marital status was measured on a nominal scale and the dependent variable of job stress was measured on an interval scale. All these conditions showed that a t-Test would be the best statistical analysis for this hypothesis. However before deciding on the correct t-Test to be used, Levene's test for equality of variances was performed. The details are as follows:

Levene's Test for equality of variances; $\mathrm{F}=3.146 \mathrm{p}=.079$

t-test for equality of means

Variances t-value Df 2-Tail Sig SE of Diff

$\begin{array}{lllll}\text { Equal } & -3.81 & 121 & .000 & 1.398 \\ \text { Unequal } & -3.82 & 113.92 & .000 & 1.395\end{array}$

Since the significance level for Levene's test is .079 that is above .025 of our two-tailed significance level $(\alpha)$, the "Equal Variances" test was applied.

The t-test showed significant differences between the mean score of 39.98 for the married female employees and a lower score of 34.66 for the single female employees $(p=.000)$. Since $p=.000 \leq .025$, the null hypothesis was rejected at .025 significance level $(\alpha)$ and the alternate hypothesis substantiated. This showed that married female employees had really higher job stress levels than the unmarried ones did. The results of the test are shown in Table. 3 below:

Table.3: Independent Samples t-Test between Marital Status and Job Stress

\begin{tabular}{|l|l|l|l|l|}
\hline Groups & $\begin{array}{l}\text { No. of } \\
\text { Cases }\end{array}$ & Mean & $\begin{array}{l}\text { 2-tailed } \\
\text { Sig. (p) }\end{array}$ & $\begin{array}{l}\text { Sig. } \\
\text { Level ( } \alpha)\end{array}$ \\
\hline Married & 61 & 39.9836 & .000 & .025 \\
\hline Single & 62 & 34.6613 & & \\
\hline
\end{tabular}

Mean difference $=-5.3223$

\section{Hypothesis 3:}

Ho: There will be no difference in job stress levels among female employees having children and female employees having no children.

Ha: There will be difference in job stress levels among female employees having children and female employees having no children.

To test for statistical significance, an Independent Samples t-Test was established. In this hypothesis, the grouping variable that is the independent variable of having children or not was measured on a nominal scale and the dependent variable of job stress was measured on an interval scale. Thus, a t-Test would be the soundest measure to apply to test this hypothesis. However before deciding on the correct t-Test to be used, Levene's test for equality of variances was performed. The details are as follows:

Levene's Test for equality of variances; $F=.380 p=.539$

t-test for equality of means

Variances t-value Df 2-Tail Sig SE of Diff

$\begin{array}{lllll}\text { Equal } & 2.62 & 121 & .010 & 1.738 \\ \text { Unequal } & 2.86 & 48.06 & .006 & 1.589\end{array}$

Since the significance level for Levene's test is .539 that is above .025 of our two-tailed significance level $(\alpha)$, the "Equal Variances" test was applied.

The t-test showed significant differences between the mean score of 40.85 for the female employees having children and a lower score of 36.30 for the female employees having no children $(p=.010)$. Since $p=.010 \leq$ .025 , the null hypothesis was rejected at .025 significance level $(\alpha)$ and the alternate hypothesis was substantiated. This showed that female employees having children had really higher job stress levels than the female employees having no children. The results of the test are shown in Table. 4 below:

Table.4: Independent Samples t-Test between Having Children or Not and Job Stress

\begin{tabular}{|l|l|l|l|l|}
\hline Groups & $\begin{array}{l}\text { No. of } \\
\text { Cases }\end{array}$ & Mean & $\begin{array}{l}\text { 2-tailed } \\
\text { Sig. }(p)\end{array}$ & $\begin{array}{l}\text { Sig. } \\
\text { Level } \\
(\alpha)\end{array}$ \\
\hline Have child & 27 & 40.8519 & .010 & .025 \\
\hline Have no child & 96 & 36.3021 & & \\
\hline
\end{tabular}

Mean difference $=4.5498$ 


\section{Hypothesis 4:}

Ho: There will be no difference in job stress levels among female employees having preschool and primary school age children and female employees having older children.

Ha: There will be difference in job stress levels among female employees having preschool and primary school age children and female employees having older children.

To test for statistical significance, an Independent Samples t-Test was established. In this hypothesis, the grouping variable that is the independent variable of having preschool or primary school-age children was measured on a nominal scale and the dependent variable of job stress was measured on an interval scale. Thus, a tTest would be the best applicable measure to test this hypothesis. However before deciding on the correct $t$-Test to be used, Levene's test for equality of variances was performed. The details are as follows:

Levene's Test for equality of variances; $F=.310 p=.582$

t-test for equality of means

\begin{tabular}{lcccc} 
Variances & $t$-value & Df & 2-Tail Sig & SE of Diff \\
\hline Equal & 3.37 & 25 & .002 & 2.745 \\
Unequal & 3.72 & 9.50 & .004 & 2.482
\end{tabular}

Since the significance level for Levene's test is .582 that is above .025 of our two-tailed significance level $(\alpha)$, the "Equal Variances" test was applied.

The t-test showed significant differences between the mean score of 42.90 for the female employees having preschool or school-age children and a lower score of 33.67 for the female employees having older children ( $p=$ .002 ). Since $p=.002 \leq .025$, the null hypothesis was rejected at .025 significance level $(\alpha)$ and the alternate hypothesis was accepted. This showed that female employees having preschool or primary school age children had really higher job stress levels than the female employees having older children. In addition it should be noted that the number of cases for this test was 27 , since only 27 female employees had children. The results of the test are shown in Table. 5 below:
Table.5: Independent Samples t-Test between Age of Children and Job Stress

\begin{tabular}{|l|l|l|l|l|}
\hline Groups & $\begin{array}{l}\text { No. of } \\
\text { Cases }\end{array}$ & Mean & $\begin{array}{l}\text { 2-tailed } \\
\text { Sig. (p) }\end{array}$ & $\begin{array}{l}\text { Sig. } \\
\text { Level } \\
(\alpha)\end{array}$ \\
\hline $\begin{array}{l}\text { Have } \\
\text { pre-sch or } \\
\text { primary-sch } \\
\text { age child }\end{array}$ & 21 & 42.9048 & .002 & .025 \\
\hline $\begin{array}{l}\text { Have older } \\
\text { Child }\end{array}$ & 6 & 33.6667 & & \\
\hline
\end{tabular}

Mean difference $=9.2381$

\section{Hypothesis 5:}

Ho: There will be no relationship between the number of children and the job stress levels of female employees.

$\mathrm{Ha}$ : The job stress levels of female employees will increase as the number of children they have increased.

In order to analyze the relationship between the dependent variable of job stress and the independent variable of the number of children, Pearson Correlation Analysis has been utilized. Since the dependent variable of job stress is measure on an interval scale and the independent variable of the number of children is measured on a ratio scale, it would be more meaningful to investigate the relationship by conducting a correlation test. However, contrary to the expectations, the test results showed a negative correlation $(r=-.32 ; p=.05)$ between job stress and the number of children. Since $p=.05 \leq .05$, the null hypothesis was rejected at .05 significance level $(\alpha)$, while the alternate hypothesis could not be substantiated. Since alternate hypothesis stated that there would be a positive relationship between job stress and the number of children, meaning that the job stress levels of female employees would increase as the number of children they had increased. However, the results showed that job stress levels of female employees decreased as the number of children they had increased. In addition it should be noted that the number of cases for this test was 27 , since only 27 female employees had children. Table 3.8 below indicates the test results:

Table.6. Pearson Correlation Results between Job Stress and Number of Children

\begin{tabular}{|l|l|l|l|}
\hline Variables & $\begin{array}{l}\text { No.of } \\
\text { Cases }\end{array}$ & $\begin{array}{l}\text { Corr. } \\
\text { Coeff. (r) }\end{array}$ & p-value \\
\hline Job Stress vs & 27 & -.3232 & .05 \\
No. of Child & & & \\
\hline
\end{tabular}


In this study, the effect of the demographic variables was also assessed to provide additional and supplementary information. For the demographic variables of age and educational level, One Way Analysis of Variance (ANOVA) tests were utilized. One-Way ANOVA helps to determine whether there are significant mean differences in a dependent variable between more than two groups. Since we aim to determine whether there are significant mean differences in job stress levels when grouped among different age and education levels, One Way ANOVA would be a sound measure to examine the research data. The test results are summarized in Table.78 below:

Table.7: One Way ANOVA Between Age and Job Stress

\begin{tabular}{|l|l|l|l|l|}
\hline $\begin{array}{l}\text { Groups } \\
\text { (Age) }\end{array}$ & $\begin{array}{l}\text { No. of } \\
\text { Cases }\end{array}$ & Mean & F prob. & $\begin{array}{l}\text { Sig. } \\
\text { Level } \\
(\alpha)\end{array}$ \\
\hline Below 25 & 46 & 38.0652 & .5434 & .05 \\
\hline Betw. 25-35 & 57 & 36.9298 & & \\
\hline Betw. 36-45 & 14 & 37.8571 & & \\
\hline Betw. 46-55 & 5 & 35.4000 & & \\
\hline Above 55 & 1 & 25.0000 & & \\
\hline
\end{tabular}

Based on the test results, we can conclude that there are no significant mean differences in job stress levels among the different age groups, since $\mathrm{F}$ probability of .54 is higher than .05 significance level $(\alpha)$. However, the analysis of the results indicate that the mean of job stress level decreases as the age increases except for the second group of 36-45 years of age.

Table.8: One Way ANOVA Between Educational Level and Job Stress

\begin{tabular}{|l|l|l|l|l|}
\hline Edu.Level & $\begin{array}{l}\text { No. of } \\
\text { Cases }\end{array}$ & Mean & F prob & $\begin{array}{l}\text { Sig. } \\
\text { Level }(\alpha)\end{array}$ \\
\hline High School & 22 & 35.9545 & .6980 & .05 \\
\hline University & 86 & 37.6047 & & \\
\hline $\begin{array}{c}\text { Master's } \\
\text { Degree }\end{array}$ & 15 & 37.5333 & & \\
\hline
\end{tabular}

According to the test results it can be observed that there are no significant mean differences in job stress levels among the different educational levels, since the $F$ probability of .69 is higher than .05 significance level $(\alpha)$.

\section{DISCUSSION}

The aim of this study was to analyze the relationship between job satisfaction and job stress of female employees and to investigate the effects of marital status, presence, age and number of children on their job stress levels. In addition, the relationship between the demographic variables, age and educational levels of female employees and job stress was also examined in order to determine whether these variables had any influence on job stress levels.

In order to achieve this aim and to test the hypotheses, various steps have been followed. The data for the study was collected via a 41-item questionnaire and administered to the female employees working in two audit companies in İstanbul. For the data analysis, firstly, frequency distributions were obtained to describe the sample. Afterwards, Cronbach's alpha was established for the dependent and the independent variables. Then, the means and the standard deviations were calculated for the dependent and the independent variables. Finally, these steps were followed with the application of different statistical analyses, such as Pearson Correlation Analyses, Independent Sample t-Tests and One Way Analysis of Variances (ANOVA), depending on the nature of the variables under study.

The results of the frequency distributions of the demographic characteristics showed that our female sample was mostly composed of employees in the age group of 25-35. Slightly more than half of the employees were married and most of them were university graduates. Only around $20 \%$ of the employees had children and most of these children were preschool or primary school age children.

The reliability analyses for the items measuring both job satisfaction and job stress ensured us that the internal consistency of measures used in the study was good, with Cronbach's alpha of .90 and .83 respectively and that there were no items to be excluded in further analyses which would endanger the reliability of the whole measure.

The results of the correlation analysis revealed that there was really a negative relationship between the dependent variable, job stress and the independent variable, job satisfaction of female employees. This showed that as the job satisfaction levels of female employees increased, their job stress levels decreased. If we put it another way, we can say that female employees who were less satisfied with their jobs expressed higher levels of job stress than the ones, which were more satisfied. This result also supports the findings of the previous researchers who claimed that there would be a negative relationship between job stress and job satisfaction [7,22-24].

The t-Test results for the effect of the independent variable, marital status on job stress levels of female employees, reveal that married female employees had really higher job stress levels than the single ones. This can be explained by the fact that when workingwomen get married, their roles at home become more demanding by 
typically trying to maintain the major responsibility for home and family. Thus the stress of being both a homemaker and career woman would to lead to proportionately more severe strains. This finding is consistent with the results of other researchers who argue that married working women were exposed to greater stress than unmarried ones [25-26].

According to the $t$-Test results, concerning the effect of the independent variable, presence of children on job stress levels of female employees, the female employees having children were found to have higher job stress levels than the ones having no children. It is very well known that parenthood exacerbates the effects of work-related stress. Working mothers experience more conflict between work and personal life, more stress and more feelings of overload as well as lack of control and mastery of their lives than other workingwomen Thus, the presence of children at home is usually associated with physical unavailability for work, preoccupation with childrearing activities and overload. This result is also supported by many researchers $[8,10,27]$.

The effect of the independent variable, age of children on the job stress levels of female employees was examined by a t-Test. The results showed that the age of children played really an important role in determining the job stress levels of female employees. Since, the female employees having preschool or primary age school children had really higher job stress levels than the female employees having older children. Consistent with the findings of Gove and Geerken [28], we can say that family demands increase at the same rate as the age of the youngest child increases. It is very clear that family responsibilities are probably most demanding and the care giving is more intensive, when children are still young and dependent. Hence the depressing effects of this cause women to be more inefficient at work, as they are mostly unable to accept new responsibilities that conflict with the time that will be devoted to family. However, this pattern diminishes for women with older children, suggesting that family-to-work influences are closely linked to stages of the family life cycle [29].

The correlation analysis between the independent variable, number of children and job stress showed that there was a negative correlation between these variables. It means that the stress levels of female employees increase as the number of children they have decreased. However, this finding was totally contrary to our hypothesis developed according to the general expectations and theories in literature. We had hypothesized that the job stress levels of female employees would increase as the number of children they have increase. Thus, we were expecting to find a positive correlation between the variables. Some researchers claimed that the stress felt by women would increase as the number of children they have increased $[7,28,30]$.
Although the result of our test is contrary to our expectations, it can shed light to other research findings. We can attribute this difference to three major causes:

1- Sample Size: This opposite result could be due to the size of our sample. Our sample was restricted to 123 employees, different results can be obtained from a larger sample size:

2- Sample Characteristics: Another fact can be due to the composition of our sample size. According to the frequency results, of the 27 female employees having children, 21 of them had one child while only 6 female employees had more than one child. Thus, if the sample had included more female employees with more children, the test results might have been different.

3- The Existence of A Moderating Variable: From another point of view, this sample composition hinders the analysis of the effect of the number of children on job stress in the way that if the employees had younger children, instead of one, maybe the results would have been different. Thus, the decrease in job stress levels by an increase in the number of children can be attributed to the age of those children, since due to the sample composition, female employees with more than one child had older children. These contradictory results in this study can shed light to other research findings in the way that the age of children could be a more important factor in determining the stress levels than the number of children. However, this may bring another undiscovered relationship into the arena. It can be a signal for the fact that, age can be a moderating variable on the number of children and job stress relationship. This means that number of children will not have any effect on the job stress levels unless these children were young. To put it differently, the relationship between the number of children and job stress will be dependent on the age of the children.

One Way Analysis of Variance (ANOVA) conducted for the effect of the demographic variables of age and educational level on the job stress levels of female employees showed that these variables had no influence on job stress. That is, the job stress levels of female employees did not differ according to various age groups and educational levels.

\section{CONCLUDING REMARKS}

This study enables us to consider the relationship between job stress and job satisfaction of female employees from different occupational levels. It highlights the different aspects and sources of workfamily conflict for workingwomen and emphasizes the effect of family on job stress levels of these female 
employees. The research hypotheses were confirmed that the more satisfied the female employees from their jobs, the less stress they felt concerning their jobs. In addition, married female employees, with younger children experienced greater stress when compared to the married female employees with older children or those having no children. However, this study brings into the arena an important finding that should be taken into consideration in future researches and that should be analyzed more thoroughly. Working mothers' job stress may increase due to the increase in the number of children they have. However the important point here is the fact that the age of children appears to play a determining role in this relationship. It shows that the number of children will not have any. effect on mothers' job stress unless these children are young. Thus, future researchers can examine this aspect in more detail.

In this study, we have measured the job stress and job satisfaction levels of female employees, by taking into consideration various factors concerned primarily with the nature of work and work environment such as working conditions, pay, promotion, supervision, co-workers etc. However, our aim was to reach a total satisfaction and a total job stress score based on our questionnaires. We wanted to find out the nature of the relationship between job stress and job satisfaction and we wanted to identify whether their total job stress level was affected by family demands such as marital status, presence, age and number of children. In this respect, we have not identified from which aspects of their jobs the female employees were satisfied or unsatisfied with, neither we have determined which features of their jobs were causing the major stress on these female employees. For this reason the needs of the female employees and the outcomes for the organizations have remained unaddressed. Hence, for further research studies factor analysis can be used for investigating the subdimensions of job stress and job satisfaction variables. In this way, the aspects of the jobs creating stress and dissatisfaction on the female employees may be highlighted.

For a more thorough study of the differences in job stress levels - which was beyond the context of this study - a comparison between the various professions in different sectors could be made. This would facilitate a possible generalization specific to some sectors. Since job stress level may vary depending on the nature of the various jobs. Spielberger and Reheiser [1] supported this argument and in their study they identified major differences in job stress levels between employees working in police departments and those working as teachers. They also pointed out the fact that job stress showed differences according to different occupational levels, such as managerial, professional and clerical. They observed that employees working at managerial levels were more stressful than the ones working at professional levels and in the same sense, employees working at the professional levels experienced higher stress than the ones working at clerical levels. These results may be due to the more work overload and higher responsibility experienced at managerial levels. Thus, in future studies, the job stress levels of female employees working at different levels may be analyzed.

Another concept that is very much related with the occupational level, is "autonomy" which can be the outcome of the occupational level itself. Piotrkowski [31] argues that jobs providing autonomy enable workers balance work and family responsibilities in a better way. She also points out that workers with autonomy are more able to schedule work tasks so that they do not interfere with family responsibilities. This can be a significant fact for improving the research in an audit firm. Since senior level and above have more autonomy when compared to the other levels and they can schedule their time more effectively than those employees at lower levels. A future research assessing the differences in job stress depending on the various job levels may be conducted.

This study did not assess the impact of overtime on job stress. Since due to the nature of audit work that require overtime mostly as a part of the job itself, it would not help for a differentiation between those female employees working overtime and those who are not. However, Spielberger and Reheiser [1] cited working overtime as a very important factor in determining the stress levels, because employees working overtime were found to be more likely to perceive their jobs as stressful. In this respect, future research can be conducted for other professions to search for the impact of working overtime on job stress levels of female employees.

This research covered the relationship between two important topics in management, job stress and job satisfaction. The other crucial topic covered in this study is the effect of family responsibilities on the job stress of female employees. Currently, many businesses in other countries are beginning to implement family supportive policies, such as parental leave, childcare provisions, eldercare programs, flexible work hours and locations and employee-counseling programs. It is assumed that these policies help workers balance work and family responsibilities [32]. So the employees who feel more relaxed can be more satisfied with their job and feel less job stress on them. 


\section{REFERENCES}

[1] SPIELBERGER, C.D.; REHEISER, E.C., "The Job Stress Survey: Measuring Gender Differences in Occupational Stress", Journal of Social Behavior and Personality 9 , 1994, p.199.

[2] EDWARDS, J.R., "A Cybernetic Theory of Stress, Coping and Well-Being in Organizations", Academy of Management Review, 17, 1992, p.251.

[3] BHAGAT, R.S.; ALLIE, S.M.; FORD, D.L.Jr., JobRelated Stress: Relationship with Personality Variables and Organizational Outcomes, Cited in GÖZNEK, A., 1997, Unpublished Master Thesis, Boğaziçi University, İstanbul, 1991.

[4] SCHAFER, W.E.; McKENNA, J.F., "Perceived Energy and Stress Resistance: A Study of City Managers", Journal of Social Behavior and Personality, 6, 1991, pp.271-282.

[5] SUMMERS, T.P.; DeCOTTIS, T.A.; DeNISI, A.S., Do Men and Women Utilize Social Support Differently in Stressful Work Environments?, Cited in ÖZCAN, B., 1997, Unpublished Master Thesis, Boğaziçi University, İstanbul, 1995.

[6] QUARSTEIN, V.A.; McAFEE, R.B.; GLASSMAN, M., "The Situational Occurrences Theory of Job Satisfaction", Human Relations, 45, 1992, pp.859-873.

[7] JUDGE, T.A.; BOUDREAU, J.W.; BRETZ, Jr.R.D., "Job and Life Attitudes of Male Executives", Journal of Applied Psychology, 79, 1994, pp.767-782.

[8] KAHN, R.L.; WOLFE, D.M.; QUINN, R.P.; SNOEK, J.D.; ROSENTHAL, R.A., "Organizational Stress: Studies in Role Conflict and Ambiguity", cited in COOF, J.D.; HEPWORTH, S.J.; WALL, T.D.; WARR, P.B., 1981, The Experience of Work: A Compendium and Review of 249 Measures and Their Use, Academic Press Inc., London, 1964

[9] DUXBURY, L.E.; HIGGINS, C.A., "Gender Differences in Work-Family Conflict", Journal of Applied Psychology, 76, 1991, p.64.

[10] VOYDANOFF, P., "Work Role Characteristics, Family Structure Demands and Work/ Family Conflict", Journal of Marriage and the Family, 50, 1988, pp.749-761.

[11] NIEVA, V.F., "Work/Family Conflict Among Women and Men managers in Dual-Career Couples in Israel", Cited in IZRAELI, D.N., 1993, Journal of Social Behavior and Personality, 8, 1985, pp.371-388.

[12] http://www.textiles.umist.ac.uk/Research/TexOnline/ Man99/WomenSingh B.htm.
[13] NELSON, D.L.; QUICK, J.C., "Professional Women: Are Distress and Disease Inevitable?", Academy of Management Review, 10, 1985, pp. 206-213.

[14] BARUCH, G.K.; BIENER, L.; BARNETT, R.C., "Women and Gender in Research on Work and Family Stress", American Psychologist, 42, 1987, pp.130-136.

[15] LONG, B.C.; KAHN, S.E., 1993, cited in http://www.ed.gov/databases.

[16] http://www.hope.edu/academic/pscyhology $7335 /$ webrep/genroles.himl

[17] BARDWICK, J.M., "Role Conflict in Women as a Function of Marital Status", cited in NEVILL, D. DAMICO, S., 1975, Human Relations, 28, 1971, pp.487. 498.

[18] JICK, T.D.; MITZ, L.F., "Sex Differences in Work Stress", Academy of Management Review, 10, 1985, pp.408-420.

[19] ZAPPERT, L.T.; WEINSTEIN, H.M., "Sex Differences in the Impact of Work on Physical and Psychological Health", American Journal of Psychiatry, 142, 1985, pp.1174-1178.

[20] ROGERS, S.J., "Mothers' Work Hours and Marital Quality: Variations by Family Structure and Family Size", Journal of Marriage and the Family, 58, 1996, p.616.

[21] WEISS, D.J.; DAWIS, R.W.; ENGLAND, G.W. LOFQUIST, L.H., "Manual for the Minnesota Satisfaction Questionnaire", cited in COOF, J.D. HEPWORTH, S.J.; WALL, T.D.; WARR, P.B., 1981, The Experience of Work: A Compendium and Review of 249 Measures and Their Use, Academic Press Inc. London, 1967.

[22] CUMMINS, R., "Locus of Control and Social Support: Clarifiers of the Relationship Between Job Stress and Job Satisfaction", Journal of Applied Social Psychology, 19 1989, pp.772-788

[23] O'DRISCOLL, M.P.; ILGEN, D.R.; HILDRETH, K. "Time Devoted to Job and Off-Job Activities, Interrole Conflict and Affective Experiences", Journal of Applied Psychology, 77, 1992, pp. 272-279.

[24] BEDEIAN, A.G.; BURKE, B.G.; MOFFETT, R.G., "Job and Life Attitudes of Male Executives", cited in JUDGE, T.A.; BOUDREAU, J.W.; BRETZ, Jr.R.D., 1994 Journal of Applied Psychology, 79, 1988, pp. 767-782.

[25] REPETTI, R.L., "Parental Employment and family Life: Research in the 1980s", cited in MENAGHAN, E.G.; PARCEL, T.L., 1990, Journal of Marriage and the Family, 52, 1988, pp.1079-1098. 
[26] BARNETT, R.C.; MARSHALL, N.L.; RAUDENBUSH, S.W.; BRENNAN, R.T., "Gender and the Relationship Between Job Experiences and Psychological Distress: A Study of Dual- Earner Couples", Journal of Personality and Social Psychology, 64, 1993, pp.794-806.

[27] BARNETT, R.C.; BARUCH, G.K., "Women's Involvement in Multiple Roles and Psychological Distress", Journal of Personality and Social Psychology, 49, 1985, pp.135-145.

[28] GOVE, W.R.; GEERKEN, M.R., "The Effect of Children and Employment on the Mental Health of Married Men and Women", Social Forces, 56, 1977, pp. 67-76.

[29] CROUTER, A.C., "Spillover from Family to Work: The Neglected Side of the Work-Family Interface", Human Relations, 37, 1984, pp. 425-442.

[30] KATZ, M.H.; PIOTRKOWSKI, C.S., "Work Role Characteristics, Family Structure Demands and Work' Family Conflict", cited in VOYDANOFF, P., 1988, Journal of Marriage and the Family, 50, 1983, pp.749761.

[31] PIOTRKOWSKI, C., "The Contagion of Stress Across Multiple Roles", cited in BOLGER, N.; DeLONGIS, A.; KESSLER, R.C.; WETHINGTON, E., 1989, Journal of Marriage and the Family, 51, 1979, pp.175-183.

[32] LAMBERT, S.J., "Processes Linking Work and Family: $A$ Critical Review and Research Agenda", Human Relations, 43, 1990, pp.239-257.

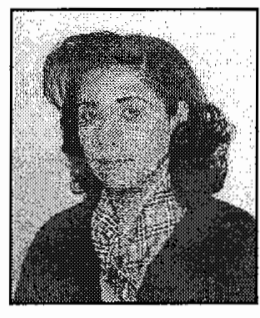

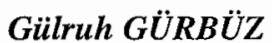

Marmara Üniversitesi, İ.i.B.F., İngilizce İşletme Bölümü, Göztepe Kampüsü 81040 Göztepe / ISTANBUL

Tel: +902163384416 gulruh@marmara.edu.tr

Gülruh GÜRBÜZ has Ph.D. of Business Administration at Marmara University Social Sciences Institute. She is Assistant Professor in Management and Organization Department at the Marmara University. Her research areas include management, and human resources management. 